\title{
THE USE OF GENEALOGIST IN THE STUDY OF HEREDITARY EYE DISORDERS IN NORTHERN FINLAND*
}

\author{
Henrik Forsius ${ }^{1}$ and Margareta DAMSTEN ${ }^{2}$ \\ 1 Department of Ophthalmology, University of Oulu, SF-90220 Oulu 22, Finland \\ ${ }^{2}$ Folkhälsan Institute of Genetics, Population Genetics Unit, Helsinki, Finland
}

Hereditary disorders have the best possibilities to be studied in countries with good population records. A stable population with large families in isolated districts are also of great help. We can find them in islands or in valleys surrounded by high mountains, or as seen in Finland in sparsely inhabited large areas isolated by distance.

Along the largest rivers some settlements with Finnish inhabitants have existed already 1000-1150 years B.C. but large parts of northern Finland have been inhabited by Finns first in last four centuries and the population has since then rapidly grown. Many of the new areas were inhabited as a result of new technology and new living habits. This is especially the fact of northern Finland where the population density still is very low. Its northernmost county, Lapland, has today only 2 persons per squarekilometer. In Japan the density is more than 100 times greater. The people found isolation as a natural thing in earlier times. E.g. in 1804 an author writes about a place in Lapland, Kittilä, that it has up to 11 persons per $100 \mathrm{~km}^{2}$, the highest population density anywhere north of the Arctic Circle. Probably it was of his opinion crowded with people. These areas were earlier inhabited by nomads, the Lapps, the original population of Finland. It is not known how many they were, but in 1570 there were 91 and in 1582, 101 households and in 1695, 150 Lappish households paid tax to the Swedish government. The Finnish speaking population trespassed slowly to the north and east of our country. The northern part of Finland, today registered as Oulu and Lapland Countries had in 1595 altogether 2,500 adults and probably the same number of children. The times were hard and the population varied in size. E.g. in 1601, 500 persons died because of shortness of food. Today the number has grown to 700,000 (Ingman, 1890; Suomen, 1973).

Finland was up to 1809 a part of Sweden, which has the oldest population register in the world. It was established 1749-1750 and made the priests responsible for the registration of the inhabitants in every house and to keep records of the births, the deaths and the marriages. We can thus get information of the living places of

Received July 13, 1982

* Read at 35th Japanese Clinical Ophthalmology Congress in Tokyo on November 23rd, 1981. 
all persons but also notes of to which places they eventually moved. The priests also made notes of all people which were blind, deaf or crippled and thus not able to pay tax. The books were rewritten every 5-10 years. We therefore can register in which age the persons got blind, which often helps us to make an educated guess which disease he got blind of. E.g. persons with severe congenital anomalies are blind from the birth, people with degenerative diseases in the eyeground often get blind as middle-aged and if you got blind first in the 60th or 70th you probably had cataract or glaucoma.

Even before the 18 th century records of the population were made. In the middle of 16 th century were all households in Finland who were obliged to pay tax for the first time registered. Figure 1 shows very clearly that the people first inhabited the coast then the rivers and lakes inside of the country and slowly moved further and further north. Later lists of the population for different purposes were irregularly made. With some luck the families can be followed back to those ancient times.

In the so-called communion books, which started in 1698, the names of the adult people and notes of their ability to read and if this did not succeed, often the cause for it e.g. blindness, etc. can be studied. Many of these books were destroyed in the war shortly afterwards. Quite reliably most individuals can be followed back to 1721, when the peace had been made because in most parts of Finland the church books after 1721 have not been destroyed in wars or by fire but are still preserved. In the 17 th century the records were less complete, but often a person living in Finland today, can be followed 10-12 generations back. In northern Finland this means back to the first Finnish immigrants in most regions.

The combination of a good population register, a young population and isolation by distance gives the human geneticists in northern Finland satisfying possibilities to study hereditary diseases. Sometimes we can find out who brought the disease to this region or in whom the mutation of the defective gene probably took place.

Finland is geographically a flat country with thousands of small lakes which form chains connected by rivers and which end at the coast. The population spread by moving from lake to lake often following the rivers. When the pioneers found a new area which could be inhabited other people either from the nearest inhabited villages or from places far away followed them. This first population had often good living possibilities and could rapidly increase. The living standard was by our standards very low in spite of this the families were large and several children reached the age of an adult. This so-called founder effect is remarkable in many areas in northern Finland. In the first generations the marrying distance was by natural causes long because marriages between near relatives as first cousins were not permitted but when the population density grow it became shorter and shorter. Very soon the area was more or less closed. After some generations the relationship to the neighbours was forgotten, and as $70-80 \%$ of all marriages were made between spouses from the same village, marriage between distant relatives were very frequent (Gustavsson, 1939). 


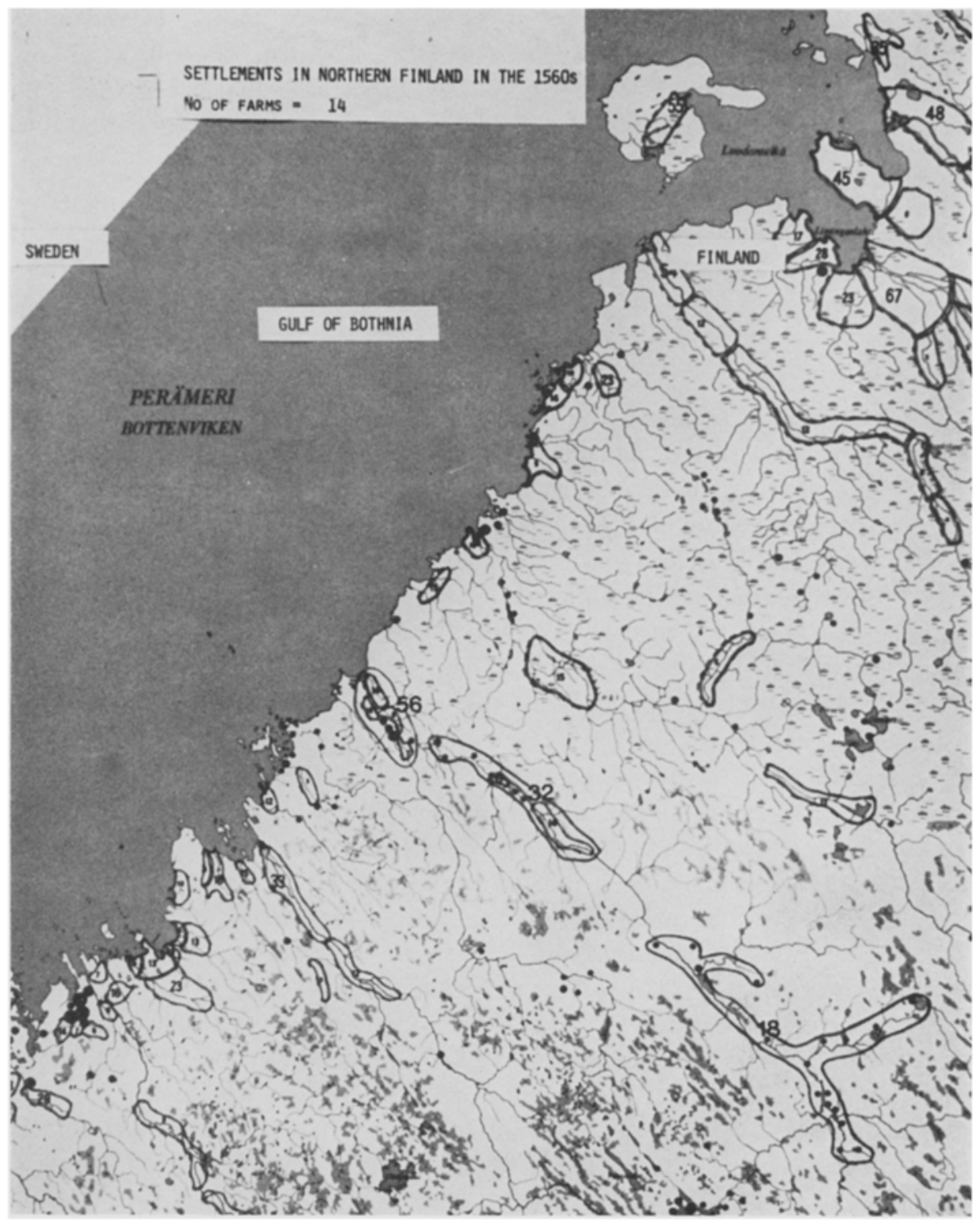

Fig. 1. Settlements in northern Finland in the 1560s.

It is therefore very often possible to establish consanguinity between persons with certain autosomal recessive diseases. Even for a layman, the doctor who wants to study a hereditary eye disorder, it is relatively easy to follow a person genealogically 5-6 generations back if the ancesters have lived in the same region during this period. If they have moved in from another counties or if we want to follow a person further back, it is the task for a genealogist who has specialized in studying 
old church books and has knowledge in the language used and of the writing style of different priests. It can e.g. be difficult to find out if a person is a servant in the farm or family member. Sometimes we cannot find evidence of a common ancestor but if the genealogical lines end up in the same household the relationship is probable.

It can happen that we do not know if a certain defect is inherited or not, e.g. in diseases with very variable expression. A disease with a low penetrance can skip one generation or the disease found in this generation can be affected only with very small symptoms, so-called "formes frustes" cases, which can be diagnosed only by a very careful investigation. Large family studies can help to solve such problems.

When we decide to investigate genetically a disorder which we know or think can be hereditary we take contact with our genealogist. In our department all patients with presumable hereditary disorders routinely have to fill in a paper where is asked for information of names, ages, and addresses of their family members. The genealogist is first given the names of the patients with the diagnose in question and the information of the relatives we have. He follows their ancestors as far back in the ascendence as possible. A relationship between these patients can in this way very often be established. The genealogist can also get names and addresses of relatives to the patients and often then helps us to find new cases.

In a dominant disease $50 \%$ of the children are affected if one of the parents has the disease. For the next generation the chance to be affected is $25 \%$ if we do not know which persons in the earlier sibship had the disease. In the following generation the chances are $12.5 \%$ and so on. In autosomal recessive diseases the chances for the other children in the same sibship to be affected is $25 \%$. In Xchromosomal diseases all girls to an affected father are carriers of the gene. $50 \%$ of the carrier's sons become sick and half of the daughters carriers. In the next generation the chance is $25 \%$ for daughter to a woman who is not known to be carrier to be conductor herself. In X-chromosomal diseases is a son to son passage not possible and they can thus be excluded from the investigation. We can also exclude the descendants to verified healthy persons in autosomally dominantly inherited diseases as well as the children to healthy females with intermediate $X$ chromosomal diseases. This way we often can save a lot of time and unnecessary works.

Usually we stop investigating a disease if the chance to find an affected is smaller than $12.5 \%$ if we do not get anamnestic information that they have eyetroubles. Even this means often that hundreds of persons must be examined. Notes in the church books about blinds can help us a lot in choosing the genealogical lines most practical to follow. Our social security system makes it possible for us to call in persons for investigations with very small costs for them. This is a very important practical point.

A physician who comes to a certain isolate can often see many cases with 


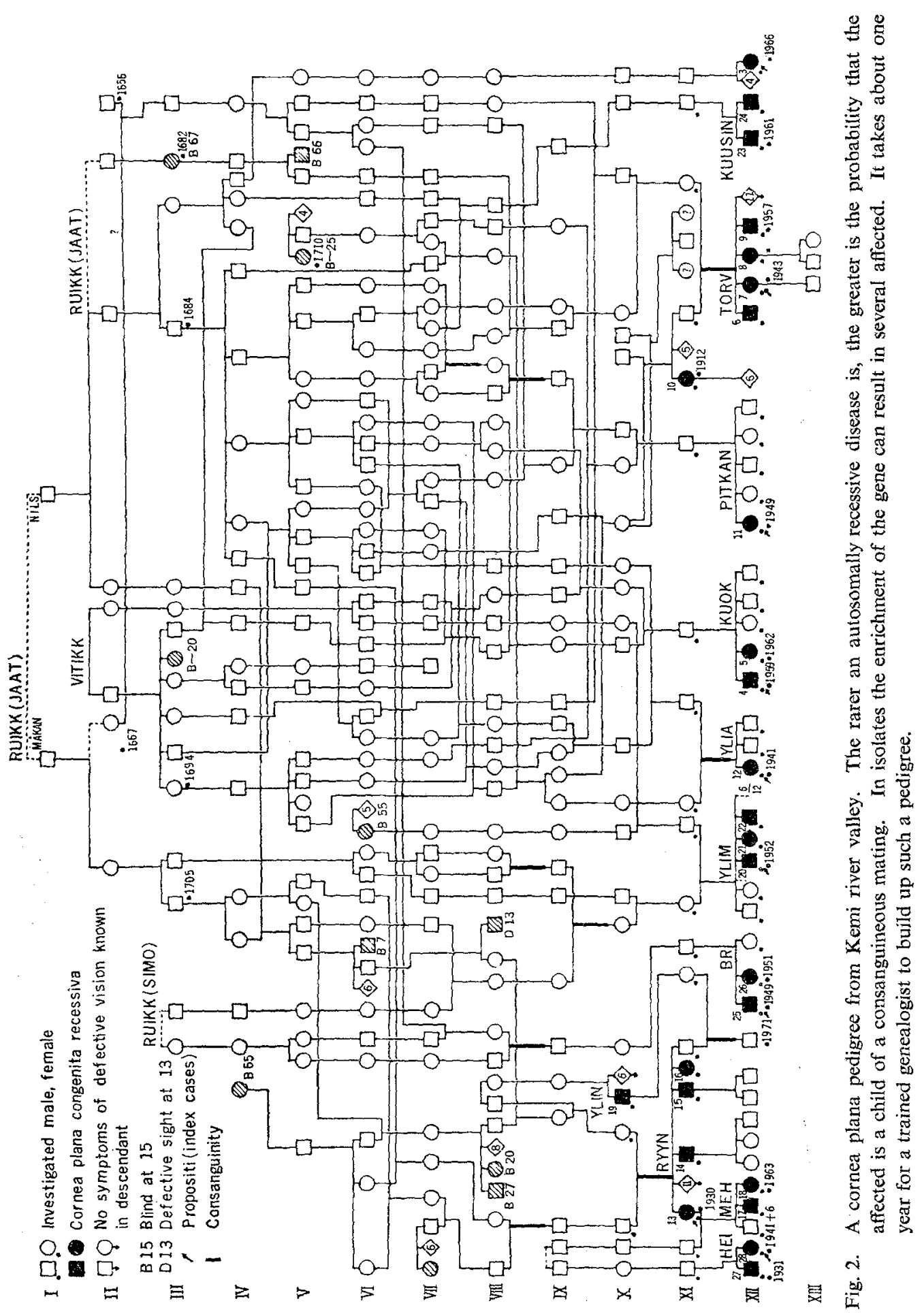

Vol. 27, No. 4, 1982 
genetical diseases typical for this district but which are very rare elsewhere. He will probably think that there is a greater number of genetical diseases in this region than elsewhere, e.g. in the population in great cities. This is not necessarily the fact, however. All of us carry several genes which can cause serious diseases but of which existence we have no idea and probably will never get knowledge of. The first inhabitants in developing isolates have probably also had an normal number of "black" genes in their genetic load. The population in the village today carries the same genes, the good as well as the bad ones. What the doctor sees is an enrichment of certain hereditary disorders, preferable autosomal recessive but also autosomally dominant and $\mathrm{X}$-chromosomal recessive diseases. But in the same region many other hereditary diseases are probably very rare which can compensate for the surplus of some diseases.

Finland can itself be named to be an isolate. In this country at least 30 elsewhere rare diseases are relatively common. But other disorders e.g. albinism are very rare and phenylketonuria is totally missing. The latter disease is seen in one child out of 5,000 in our neighbour country Norway. Norway is also made up of isolates, and the gene for phenylketonuria happens to have been enriched in its population (Vahtola, 1980).

As a very typical example of the pattern of hereditary Finnish diseases we can present cornea plana (Eriksson et al., 1973). The absolute majority of all cases with this autosomal recessive disease published in the literature are born in northern Finland. The normal protruding of the cornea is missing, the corneal refraction power is therefore very low and the patient about 10 diopters hyperopic. We started the study of this disease by giving to the genealogist the names and other facts of all patients which had visited our hospital. She studied thier genealogy as far back as possible and found connections between most of the affected persons, some of them first in the 12th generation back. Most of the ancestors came from the valley of Kemi river (Wahlenberg, 1804; Vahtola, 1980). We conclude that the gene for cornea plana must have been introduced by the immigrants to this region at least 400 years back.

\section{REFERENCES}

Eriksson, A.W., Lehmann, W., and Forsius, H. 1973. Congenital cornea plana in Finland. Clin. Genet. 4: 301-310.

Gustavsson, A.A. 1939. Maanjaot ja kylämuodostumat Pohjanmaalla. I osa, Peräpohjola, Helsinki.

Ingman nyk, Ivalo, S. 1890. Tutkimuksia Pohjois-Suomen historiasta vuosilta. Akateeminen väitöskirja, Helsinki, pp. 1595-1635.

Suomen asutus 1560-luvulla. 1973. Kyläluettelot. Helsingin yliopiston Historian laitoksen julkaisuja, No. 4, Helsinki.

Wahlenberg, G. 1804. Geografisk och ekonomisk beskrifning om Kemi Lappmark i Vesterbottens höfdignsdöme. Carl Delén, Stockholm.

Vahtola, J. 1980. Tornionjoki- ja Kemijokilaakson asutuksen synty.

Jpn. J. Human Genet. 


\section{京都府立医科大学增田正典名誉教授のご逝去を悼みて}

增田正典先生は, 菊の香薰る昭和 57 年 11 月 4 日午前 8 時 30 分, 母校付属病院の病床で 67 藏の豪放な人生を閉じられました。

先生は大正 4 年 7 月 31 日兵車県上月町に技生をれになり，昭和 15 年に京都附立医科大学家御 卒業, 直ちに母校胃腸科学教室に入局され, 本学会の発起人の一人で、らした川井銀之助教授のも之 で研鑽安つまれ，30 年第 1 回総会 (東京) の折はテキサス大学癌研に留学して括られましたが，翌 31 年の第 2 回総会 (奈良) には「家族性脾腫」の演題でシン尗シウムに参加されて以来 26 年間, 本学会の会員, 評議員として活躍され，33 年には川井教授の後を継いで京府医大第三内科学講座教

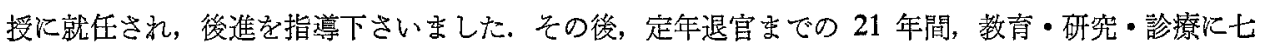
面八臂の活翟をされ，43 年には付属病院長，看護学院長の重責を果たされ，学内にとぞるらず，消 化器病学会, 血液学会, 臨床血液学会など 8 学会の理事, 加えて本学会, 臨床血液学会, 血液学会, 体質学会など 18 学会の会長を務められきした. 血液学, 消化器病学はもららんのこと, 人類遺伝学 の臨床への応用を常に心掛けられ，学内外の若い学徒の育成に常に心遗いされたことは多くの方市の

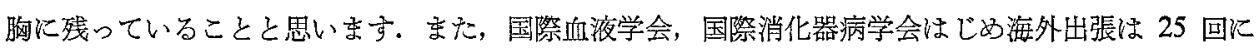
及び, 国際内視鏡学会名誉会長, 世界消化器病学会事務局長, 国際血液学会理事などの要職を歴任さ れたことは，国際人としての片鱗をらかがい知らせます４４年，関連諾学会の先生方の御推挙を受

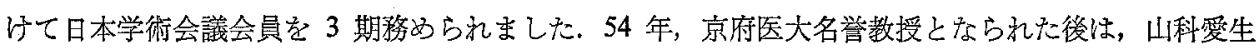

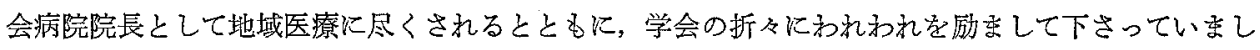

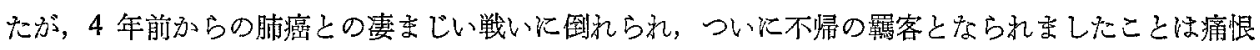
の極みです.

先生の豪放唇落な人柄, 卓越して指導力, 警くべき包容力を慕って, 一時は 150 人をこす大学き っての大世带となり，研究室も十指にあるる課題を揭げて学内外に私淑する人々も多かった。一面，

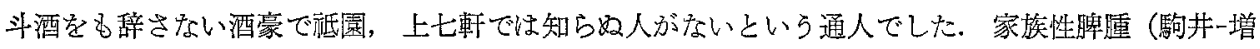
田家系として特異な遗伝様式を示し，未解決な面も残されていますが) をはじめ，消化器粘膜のりン 酸代謝, 異常血色素症, 先して隔離集落に括汓集団遺伝学的研究など, 私どもがライフワークとし ている仕事の多くが先生の御指導によって形造られたわけです。地中海性貧血をはじる多くの遗层性 疾患の分布とその伝播江興味をもたれ，御自身でンルクロードを踏破されるなど，乞の非凡な洞察力 には敬服の汸がりませでした。

37 年に教授就任以来初めての学会会長として第 7 回日本人類遺伝学会を担当され，故厝井卓京大

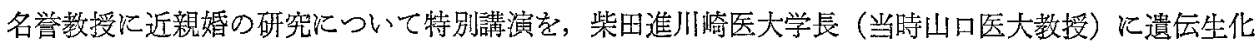

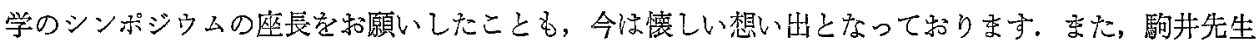
の 80 歳の誕生日を和祝いして企画された書「遺伝の臨床」(医学書院)は，当時履床医になじみの薄 かった人類遺层学の知識を平易に解説しようと，30 人近いわれわれの研究室員総勢が分担執筆して， 增田先生に編集していただき，やっと 84 歳の誕生日に和渡しできたことも楽しい想い出の一つで す. ミンガン大学人類遗伝学教室ニール教授の和計いで 7 年間にわたって米国公衆衛生院一般医学

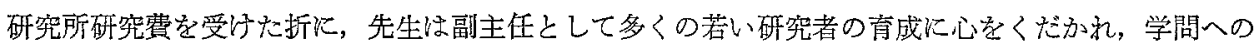
情熱と若き人ふへの支援を常に続けられるした。

ここに, 恩師堌田正典名誉教授の追悼文を揭げ，最後に拙句を捧げて，心示ら先生の御冥福を会員 の諸先生方とともに就祈り申し上げます。

師を偲ぶ 遺影煎に 走馬灯一杏孫一

(藤木典生 福井医科大学内科)

Vol. 27, No. 4, 1982 